\title{
지방중도시 주거지형성과정을 통해 본 주거지 유형분석 : 군산, 목포를 대상으로
}

본 연구목적은 지방 중도시의 주거지문제를 파악하고자 중도시를 대상으로 주거지형 성 공간구조를 분석하는 것이다. 연구대상은 인구가 감소하는 지방중소도시 중 유사 한 도시형성과정을 겪은 두 도시, 군산과 목포를 대상으로 하였다.

연구단계는 1단계로 문헌과 정책고찰을 통해 주거지유형을 주거지를 형성하는 사업단 위로 분류하였다. 2 단계로 건축물대장을 이용하여 한국전쟁이후 최근까지의 주거지 형성의 공간구조를 분석하였다. 3단계 주거지 공간구조의 변화속에서 목포와 군산의 주거지를 유형화하고 주거지유형별 특성을 분석하였다.

연구의 주요결과는 첫째, 주거지를 형성하는 과정을 살펴보면 도시화과정에서 주거지 는 정부주도의 정책을 실현하는 단위사업별로 특성이 구분되었다. 둘째, 연구대상으로 선정한 목포와 군산의 주거지공간구조는 기존지역의 주거지에서 신규개발사업과 재개 발, 재건축사업을 통해 주거지의 공간구조가 확장되는 형태를 보였다. 셋째, 주거지유 형별로 쇠퇴도, 활력도, 생활편의성을 조사한 결과 기존지역과 신규조성지역 간 차이 가 뚜렷하게 나타났다.

이를 고려할 때 향후 주거지재생은 주거지유형별 특성에 맞는 정책방향으로 정비·재생 이 필요하다고 판단된다.

* (제1저자) 한국토지주택공사 토지주택연구원, 수석연구원, email : khjkahn@lh.or.kr

※ 본 연구는 토지주택연구원(2019), 인구감소시대 지방중소도시 주거지실태 및 재생방향 연구의 일부를 발췌한 것임.

※ 본고의 내용은 필자의 개인 의견으로 한국주택금융공사의 공식적인 견해와 다를 수 있습니다. 


\section{I. 서론}

2015년 인구주택총조사에 따르면 인구증가 둔화(2010년 대비 2.7\% 증가), 고령인구비율 증 가(1985년 4.3\%에서 2015년 13.2\%), 생산연령 인구둔화(2010년 대비 0.1\%증가)등 인구 구 조 변화가 진행되고 있다. 이는 경제 저성장(2\%대), 수도권 집중(2010년 46.3\%에서 2015년 49.5\%)심화와 더불어 수도권을 제외한 지방도시들의 어려움을 가중시키고 있다. 이에 반해 정 부 지원사업은 지방중도시보다 대도시(광-특별시 및 50만 이상) 중심으로 선정되고 있다. 이런 점을 고려했을 때 인구축소가 빠르게 진행되는 지방 중소도시의 주거지부터 노후화와 축소가 동시에 진행될 것으로 예상되는바, 중소도시의 주거지에 대한 정책적 검토가 필요하다.

기존 주거지 정비·재생사업을 보면 50만이상의 대도시는 재건축 및 재개발, 공동주택방식, 현지개량등 다양한 접근이 이루어졌으나 지방중소도시는 사업성이 낮아 활발한 정비사업이 이 루어지지 않았다. 국비지원사업으로 진행된 주거지 정비·재생사업은 기반시설 위주의 국비지원 정비, 주민참여의 부족, 원주민들의 재정착율, 개별주택개량의 미흡 등의 한계점이 지적되고 있 지만, 지방중소도시는 정비계획, 전략계획 등의 부재로 정확한 실태파악 조차 어려운 실정이다.

본 연구의 목적은 인구감소의 영향을 가장 많이 받는 지방 중도시의 주거지문제를 파악하고 자 중도시를 대상으로 주거지형성 공간구조를 분석하는 것이다. 이를 통해 주거지의 공간구조 와 그 과정에서 형성된 주거지들을 유형화하고 각 유형별 특성을 조사하였다. 본 연구는 주거지 공간구조의 형성과정 및 변화과정에서 주거지를 유형화하였다는데 학술적 의의가 있을 뿐만 아 니라 유형별 특성을 조사하여 향후 주거지 유형에 따른 맞춤형 재생방향 설정에 기여할 것으로 사료된다.

본 연구에서 다루고자 하는 중소도시의 규모는 인구 30만 이하의 도시로 설정하였다. 1995 년 대비 2017년 인구증감율을 보면 30만 이상 도시들은 인구가 꾸준히 증가(30-50만 인구지 역 연평균 $1.5 \%$ 증가, 50 만이상비수도권지역 연평균 $1.35 \%$ 증가, 광역시 연평균 $1.03 \%$ 증가)) 하였지만 30만을 경계로 인구가 정체되거나 감소하는 경향(15-30만인구지역은 연평균 $0.48 \%$ 증가, 5-15만 인구지역은 연평균 $-0.81 \%$ 감소, 5 만 이하 인구지역은 연평균 $-1.13 \%$ 감소)을 보 이고 있다. 따라서 본 연구에서는 인구감소의 경계성을 보여주는 30만이하의 도시 중에서 도시 의 형성과정이 유사한 목포, 군산을 설정하였다. 두 지역을 선정한 이유는 동일한 호남생활권이 고 도시규모가 유사하고, 두 지역 모두 일제 강점기에 성장한 항구도시로 공간구조형성의 외부 요인이 유사한 점에서 선정하였다. 
연구방법은 크게 세단계로 첫째, 문헌과 정책고찰을 통해 주거지를 형성하는 사업단위를 도 출하여 주거지유형을 분류하였다. 둘째, 건축물대장을 이용하여 한국전쟁 이후 최근까지의 주 거지 형성 공간구조를 분석하였다. 셋째, 주거지 공간구조의 변화속에서 목포와 군산의 주거지 를 유형화하고 주거지유형별 특성을 분석하였다. 이를 종합하여 향후 주거지재생정책의 방향을 제시하였다.

\section{II. 주거지정비·재생정책의 변화를 통해 본 주거지유형}

\section{1. 주거지정비·재생정책의 흐름}

주거지의 정비·재생 관련한 정책은 1973년 「주택개량촉진에 관한 임시조치법」제정에서부터 시작되었다. 이 법의 제정취지를 '건축법 기타 관계법령의 규정에 위반하거나 그 기준에 미달한 건축물을 정비·개량하기 위하여 도시계획법상의 재개발사업에 관한 일부 특례를 규정하려는 것임'이라고 밝히고 있는 것과 같이 최초의 공공주도 주택재개발사업을 규정하고 있다. 당시 이 법에 의해 대규모 달동네철거사업이 시행되었고 집단적인 정책 이주지가 형성되었다. 이 법은 도시재개발법(1976.12.31제정)에서 재개발구역으로 지정된 곳에 대한 실질적인 사업법 성격 으로 제정당시부터 1981년 12월 31일까지의 기간을 설정해 놓은 한시적인 법이었다. 이 법을 통해 소위 재개발이라는 개념의 정비기법이 새로이 도입되었다. 즉 도시계획법에 근거하여 재 개발구역을 지정하고 사업을 추진함으로써 도시정비사업의 보다 계획적인 추진을 도모하였다. 이 법에 의거 소위 자력재개발이라는 사업이 추진되기 시작하였는데, 기반시설은 공공이 공급 하고 주민들이 주택을 개량하는 방식이었다. 1974년부터는 자력재개발을 추진함에 있어 일시 에 전면적인 구획정리사업을 시행하는 것이 여의치 않음을 인정하고 점진적인 사업추진도 가능 토록 하였다. 1983년부터 합동재개발방식이 서울을 중심으로 시작되었는데, 이는 민간건설업 체를 참여시킨다는 면에서 위탁재개발과 유사하나, 조합이 여유분 주택을 추가 건립하여 분양 하고 그로부터 생긴 분양수입을 재개발비용으로 충당한다는 점에서 차이가 있다. 이 사업은 세 입자에 대한 대책부족으로 거센 반발에 부딪쳐 1991년부터 재개발구역의 세입자에 시영 공공 임대주택을 공급하기도 하였다.

1972년 제정된 주택건설촉진법이 1987년 개정되면서 재건축사업의 법적 근거가 마련되었 
고 1988 년 동 시행령의 개정으로 재건축조합의 설립을 시작으로 일반주택건설사업이 구역지정 없이 진행되기 시작하였다. 재건축이 도입될 당시 단순히 노후공공주택문제의 해결을 목적(20 년 이상 경과된 주택, 초기 단독주택도 허용하였으나 1993년부터 제외)으로 도입되었기 때문 에 도시정비사업이라는 인식보다는 주택사업으로서만 인식되었다. 대도시에서는 개발가능지가 고갈되자 재건축사업이 중요한 택지확보 수단으로 사용되기도 하였다(건설교통부, 2000).

1989년 4월「도시저소득주민의주거환경개선을위한임시조치법」을 제정하여 도시의 저소득 주민밀집거주지역의 주거환경개선을 위한 임시조치법을 제정한다. 이 사업은 1980 년대에 서울 을 중심으로 한 재개발사업이 활성화되었지만 지방도시는 사업성 부족으로 추진이 어려워 나름 의 대비책으로 임시법을 제정한 것이다. 주거환경개선사업은 공동주택방식, 현지개량방식, 그 리고 복합방식으로 나누어졌다. 이를 통해 기존의 ‘재개발구역'을 ‘주거환경개선지구’로 명칭을 변경하여 노후불량건축물이 밀집된 지역 또는 공공시설의 정비 상태가 불량하여 주거환경이 열 악한 지역의 주택의 건설, 건축물의 개량, 공공시설의 정비, 소득원의 개발 등의 사업을 할 수 있게 하였다. 이 법 또한 공공주도, 당시 주택공사를 통한 정부사업으로 진행되었다. 이 법은 2002년 「도시및주거환경정비법」으로 새롭게 정비되어 지금에 이르고 있다.

「도시 및 주거환경 정비법」의 제정으로 주거지정비·재생 법률은 도시계획 체계안으로 통합 되어 계획적 정비시대를 맞이하게 되었다. 이 법에 근거하여 주거환경개선사업, 재개발, 재건 축, 도시개발사업 등 정비사업이 진행되었는데, 특히 주거환경개선사업은 공동주택방식과 현지 개량방식으로 구분되어 공공지원사업으로 2 단계까지 추진된바 있다. 주거환경개선사업의 현지 개량방식은 기반시설을 지원해주는 것으로 사회·경제적 지원시설 부족, 세입자 대책 미흡, 개 별주택 정비 미흡 등 문제점이 지적되었다. 현지개량방식을 개선하기 위해 2006년 2단계사업 중 12 개 지구를 거점확산형 주거환경개선사업 시범사업을 추진하였으나 사업지원, 필지단위 정비 지연 등 문제점이 드러났다. 이후 2009년 국가균형발전특별법」이 개정되면서 2단계사업 은 도시활력증진지역사업과 통합하여 현지개량사업이 진행되었다.

도정법에 의한 주거환경정비사업의 활성화를 위해「도시 재정비 촉진을 위한 특별법」이 2006년 7월 시행되었는데, 도시의 낙후된 지역에 대한 주거환경개선과 기반시설의 확충 및 도 시기능의 회복을 위한 사업을 광역적으로 계획하고 체계적이고 효율적으로 추진하고자 하였다. 2006년부터 재정비촉진지구를 지정하여 2014년 기준으로 총 60개 지구가 지정되었으나 대부 분 광역시이고 도단위는 강원 두 곳, 경북 한 곳, 전남 한 곳, 충남 한곳이다. 이는 정비기본계획 은 특별시·광역시·인구 50만이상의 시에서 의무적으로 수립하도록 되어 있기 때문에 광역시와 대도시위주로 수립되었다. 촉진지구 내에서는 도정법사업(재개발, 재건축, 주거환경, 도시환 
경), 도시개발사업, 도시계획시설, 시장정비사업이 가능하고 주거지형, 중심지형, 고밀복합형으 로 시행되었는데 2014년까지 총 20개 지구가 해제되어 진행이 원활하지 못하였다.

「국가균형발전특별법」은 2004년 제정되었으나 주거지관련 사업은 2009년 개정된 법률에서 '기초생활권'사업을 시작하면서부터이다. 기초생활권사업은 마을단위사업으로 전국지역을 도 시활력증진지역, 성장촉진지역, 일반농산어촌지역, 특수상황지역으로 구분하여 공모방식으로 진행되었다. 이 중에서 주거지관련 사업은 도시활력증진 지역에서 시행된 네 가지 사업(기초생 활기반 확충, 중심시가지재생, 주거지재생, 지역역량강화)에서 주거지재생에 해당된다. 도시활 력증진 지역은 96개 시, 군, 구 및 도농복합형태의 시를 제외한 지역(단 도농복합형태의 시중 인구 50만이상의 대도시는 포함)으로 규정하고 있다. 이를 통해 지자체 주민중심의 도시재생사 업을 추진하도록 하고 있다. 그리고 일반농산어촌지역은 120 개 시, 군 지역(다만, 도농복합형 태의 시 중에서 인구50만 이상의 대도시는 제외)을 대상으로 농어촌 특성에 맞는 정비사업을 시행하였다. 일반농산어촌사업 중 주거지정비와 관련된 사업은 읍면소재지 정비사업으로 2015 년 이후 중심지활성화사업으로 변경되어 시행되고 있다. 이법에 의해 시행된 도시활력증진지역 은 2017년 도시재생특별법에 의한 도시재생뉴딜사업과 통합되었고 일반농산어촌사업의 중심 지활성화사업은 그대로 시행중이다. 이외 균특법에 의해 2015년 도시와 농촌지역에 각각 새뜰 마을사업이 공모방식으로 진행되었고 이 또한 2017년 도시재생뉴딜사업이 시작되면서 조정되 었다.

「도시재생 활성화 및 지원에 관한 특별법」은 2013년6월에 제정되었는데 본격적으로 도시의 주거·경제·사회·문화적 환경을 지속가능하게 관리하는 법안을 제정하였다. 제정사유를 보면 이 법을 통해 '계획적이고 종합적인 도시재생 추진체제를 구축하고, 물리적·비물리적 지원을 통해 민간과 정부의 관련 사업들이 실질적인 도시재생으로 이어지도록 함으로써 궁극적으로 지속적 경제성장 및 사회적 통합을 유도하고 도시문화의 품격을 제고하는 등 국민 삶의 질을 향상시키 는데 기여하려는 것'이라고 하고 있다. 법제정 이후 2014년 선도사업을 시작하였고 2017년 문 재인정부 출범이후 여러 사업들을 통합조정하여 ‘도시재생뉴딜사업'으로 진행되고 있다.

2017년 도시의 빈집증가와 소규모단위 정비사업의 필요성이 증가하자 「도시 및 주거환경정 비법」과 별도로 「빈집 및 소규모 주택 정비법(2017.2.8제정)」을 제정하였다. 이를 통해 소규모 정비사업의 활성화를 도모하고자 하였는데, 자율주택정비사업, 가로주택정비사업, 소규모재건 축사업을 규정하고 빈집정비, 건축규제완화, 임대주택건설 등의 특례규정과 정비지원기구 지 정, 임대관리업무지원 등의 지원규정을 신설하였다. 
<그림 1> 주거지 정비·재생정책과 사업 변화과정

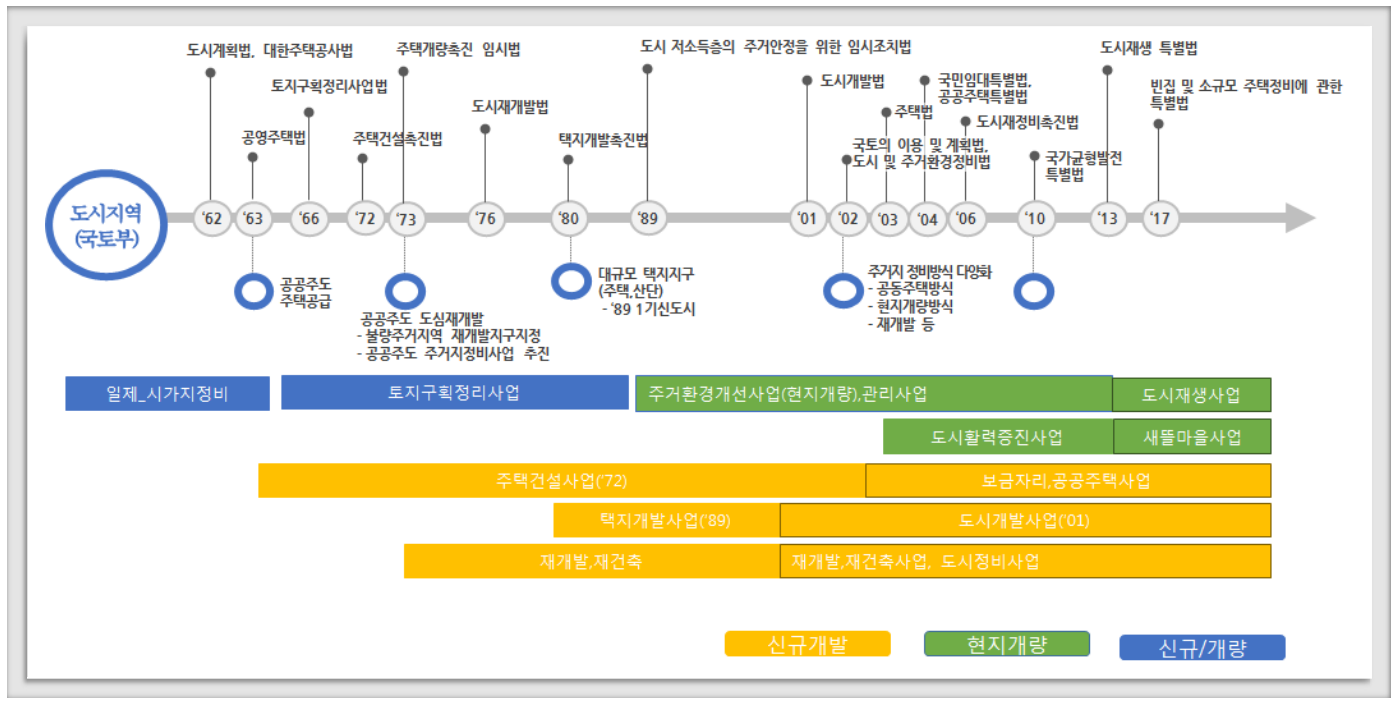

이와 같은 일련의 주거지 관련 정비·재생정책의 흐름을 정리하면 〈그림 1)과 같다. '60년대 대규모 공공주택공급이 되면서 기존 노후불량주거지의 재개발수요가 증가하자 임시적으로 재 개발지구지정을 통한 공공주도사업을 시행한 것이 주거지정비의 시작이었다. 이후 도시계획차 원의 주거지정비가 시행된 2002년부터 전국적인 주거지정비·재생사업이 진행되었으나 재재발 이 아닌 현지개량방식은 한계에 부딪치게 되었다. 이에 주거지재생은 도시차원으로 확대되면서 물리적 재생을 포함한 사회·경제적 재생까지 아우르는 도시재생에 대한 정책전환과 함께 지자 체 공모방식의 현지개량형/주민참여형으로 전환되었다. 이러한 기조는 더 강화되어 대규모 주 거지정비보다는 규모를 줄이고 주민주도, 현지개량형, 복합형 등 다양화되고 있다. 이 과정에서 물리적 재생과 사회·경제적 재생, 주민참여, 사업체계 거버넌스 구축 등 열린 방식의 사업추진 방향으로 진화해 가고 있다.

2000년대 이후 주거지관련 사업은 대부분 공모방식으로 진행되어왔다. 도시정비법에 의한 정비사업, 그중에서도 주거환경정비사업이 가장 규모가 크고, 균특법에 의한 도시활력증진지역 사업 중 주거지재생형사업, 새뜰마을사업(도시, 농촌), 도시재생사업(선도, 일반)이 있다. 〈그림 2)는 2000년대 후반부터 공모방식으로 진행되어온 주거지정비·재생사업들의 변화를 나타낸 것이다. 


\section{<그림 2> 주거지 정비·재생관련 지원사업 유형별 내용}

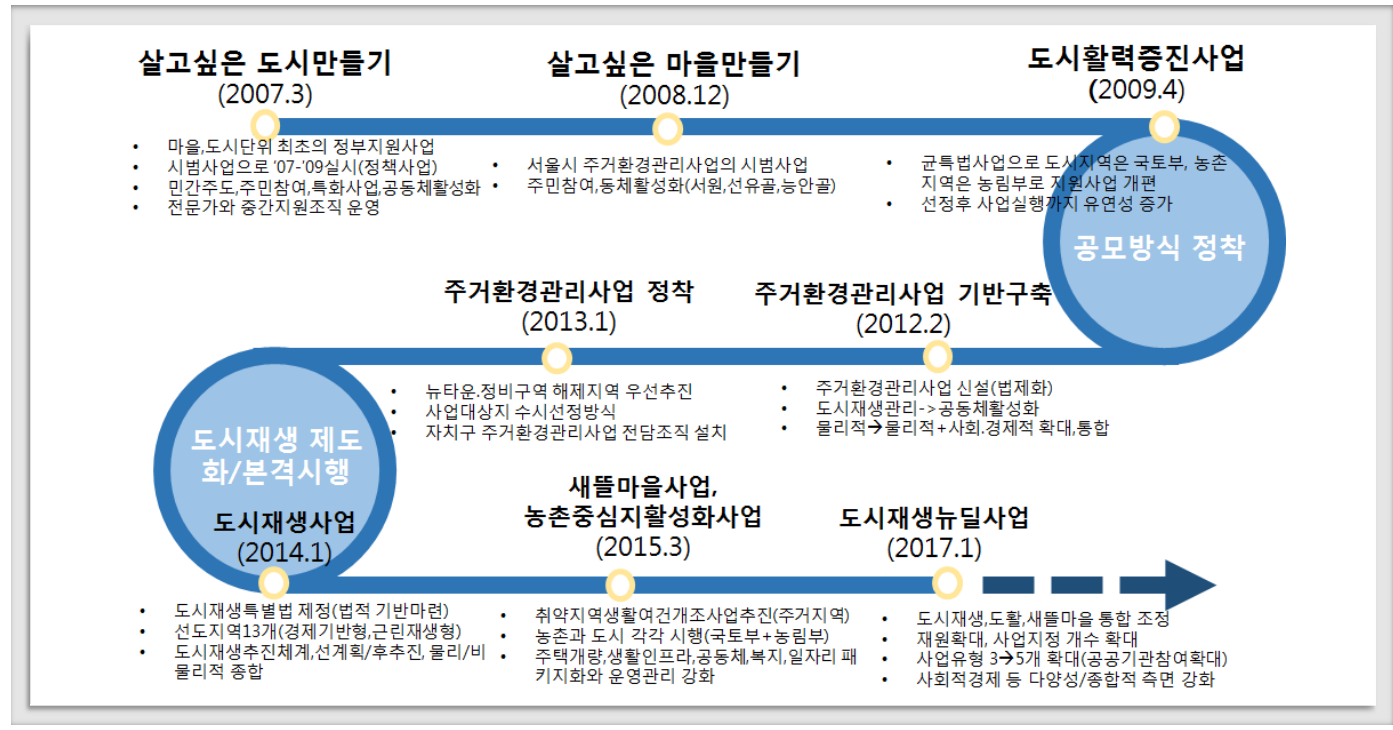

2007년 국토부는 국토의 이용 및 계획에 관한 법률에 근거한 정책사업으로「살고 싶은 도시 만들기」시범사업을 실시하면서 주민참여의 공모방식시대를 시작하였다. 이 사업은 주거지역 에만 국한되기 보다는 중심시가지지역에서 활발히 진행되었다. 이후 균특법을 제정하여 전국토 를 도시활력 증진지역, 성장촉진지역, 농산어촌지역, 접경지역으로 구분하고 공모사업을 시행 하였다. 이 중 도시활력 증진지역은 주거지재생형을 만들어 주거지역에 대한 재생사업을 본격 화하였다. 이후 도시재생특별법이 법제화되면서 사업유형을 세분화하고 2017년 도시재생뉴딜 사업으로 재구조화하여 지금에 이르고 있다. 그 중간에 새뜰마을사업은 국토부와 농림부가 동 시 시행한 것으로 도시지역은 국토부가 담당하여 취약한 주거지역에 대한 종합적 재생사업(물 리+사회경제적 재생 포함)을 시행하였다. 이를 보면 도시지역과 농촌지역을 양분화하여 각각 사업이 추진되어 왔다는 점도 분명히 알 수 있다. 다만 최근 공모방식으로 사업이 전화되면서 일부 통합 내지 사업내용이 유사해 지는 경향을 볼 수 있다. 정부의 주민참여형 공모방식은 지 자체의 주거환경관리사업에도 반영되어 광역시와 수도권을 중심으로 2008년부터 마을만들기 사업에서 시작하여 다양한 브랜드로 시행중이다. 주거환경관리사업은 서울을 비롯한 일부 지자 체에서 시행된 것으로, 서울시는 2008년 '살고싶은 마을만들기 시범사업'을 시작으로 2010년 부터 본격화하였다. 위에서 살펴본 주거지정비·재생정책의 변화를 보면 주거지를 형성하고 성 장, 정비, 재생의 가장 큰 요인은 정부정책 사업임을 알 수 있다. 2장에서 다룬 정책사업들은 추 후 주거지를 형성하는 유형으로 분류하여 좀 더 다루게 될 것이다. 


\section{2. 주거지유형화 구분}

앞절에서 살펴본 주거지정비·재생정책의 흐름을 통해 주거지가 형성되는 다양한 방식을 살펴 볼 수 있었다. 이를 토대로 주거지유형을 크게 한국전쟁이전 형성된 기존지역과 법률에 의해 신 규로 조성된 지역으로 구분하고 이를 다시 사업단위와 입지특성으로 구분하였다. 기존지역은 기존시가지지역(상업인접, 주거취약, 주거전이지역), 주거환경개선사업으로 구분하였다. 주거 환경개선사업은 한국전쟁이전에 형성된 주거지에 대해 정비사업을 시행한 곳으로 기존시가지 지역과 구분하였다. 그리고 기존시가지지역을 상업인접, 주거취약, 주거전이지역으로 구분한 것은 용도지역에서 오는 주거지의 형태를 반영하였고 기존시가지지역 인근에 신규개발지역들 이 생기면서 전이지역형태와 노후화가 심한 지역들이 나타나고 있어 이를 구분하였다. 신규지 역은 법률에 근거하여 새롭게 조성된 주거지로 택지개발사업과 토지구획정리사업, 재건축·재 개발사업으로 구분하였다. 토지구획정리사업은 1966년 토지구획정리사업법에 의해 조성된 지 역으로 1980년 택지개발촉진법이 제정되면서 종료되었다. 다만 1980년 이후에도 일부지자체 에서 토지구획정리사업을 시행하여 1980년 이전과 이후를 구분하였다. 택지개발사업은 택촉법 에 의해 조성된 주거지인데 1990년대 택지개발기준이 변경되어 1990년 이전과 이후를 구분하 였다. 특히 1990년이전은 주택공급을 위한 공동주택단지가 많아 이를 대상으로 하였다. 그리 고 2000년이후 공동주택을 대상으로 한 재건축사업도 주거지형성의 유형으로 구분하였다.

각 주거지유형별 실태조사는 세가지 측면을 주로 살펴보았는데, 쇠퇴도, 활력도, 생활편의성 이다. 주거지형 도시재생(도시새뜰마을사업, 도시재생주거지원형 등)의 지표로 많이 사용하고 있는 지표들 중 주거지의 특성을 보여줄 수 있도록 얼마나 쇠퇴하였는지, 그리고 현재 활력은 어느정도인지, 주거지역으로서 갖추어야 할 기반시설은 적정한지를 측정하고자 하였다. 먼저 주거지의 쇠퇴도는 건축물의 노후도와 소필지비율을 조사하였다. 그리고 활력도는 주거지역내 유입(유동인구, 거주인구)을 볼 수 있는 근생비율이나 빈집, 신축주택비율을 조사하였다. 생활 편의성은 주거지역의 생활SOC 측면을 다룬 것으로 공원, 주차장, 어린이집, 커뮤니티시설을 조사하였다. 


\section{III. 지방중소도시 주거지형성과정: 군산, 목포}

\section{1. 군산의 주거지형성과정 변화}

군산시의 해방이후 작성된 지도를 통해 공간구조의 변화를 살펴보았다(그림 3 참조) 군산시 는 1899년 개항이후 조계지가 설치되고 일본인 거류지(금동, 영화동, 장미동, 중앙로1가, 신창 동, 신홍동, 월명동 일대)를 중심으로 외국인들의 거류지가 형성되기 시작하였다. 도심은 내항 을 중심으로 각국 조계지를 구획하였고(1899 1905년) 항만(군산항), 철도(호남선, 군산선), 도 로건설이 되면서 기반시설이 갖추어지게 되었다. 1930년대까지는 주요 공공업무 기능을 담당 하는 건축물과 항구, 도로, 철도 등이 조계지역에 집중적으로 건설되었으며, 동시에 시가지도 확장되었다. 1926년 부터 1945년까지 군산항 및 군산시가지 확장이 지속되었으며, 철도선이 증설되고 1938 년 조선시가지 계획령을 바탕으로 한 최초의 군산 도시계획을 수립하기도 하였 다. 군산의 공간구조의 중심틀은 이 시기에 형성되었다고 볼 수 있다.

광복이후 군산은 1970 년대 이후 외항건설과 공업 및 산업화전략에 맞춰 서부중공업지대, 기 존의 동부공업지역은 경공업지대, 중앙동 일대는 주거지역과 상업지역, 월명산은 녹지지역으로 구분하였다. 1980년대 서해안개발계획이 구체화되면서 군산지방산업단지(임해공단), 금강하구 둑, 군산신항만 및 군산국가산업단지, 새만금 간척사업을 계획하였다. 1990년대는 택지개발 및 주거환경개선사업 등으로 주택 보급이 급속도로 진행되었고 주로 단지개발에 따른 아파트가 많이 공급되었다. 2000년대 이후 군산시는 재개발계획과 함께 역사문화환경을 적극적으로 보 존하려는 계획이 서로 맞물린 시기로 서해안 개발과 원도심 일대의 근대문화자원을 활용한 관 광사업들이 진행되었다. 2005년 군산 근대역사문화경관 가꾸기에서 근대건축물의 보존정비 방 법 및 관리지침의 하나로서 원도심 블록의 근대건축물을 가로경관 차원에서 관리하는 방안을 모색하기도 하였다. 또한 2007년 군산시 원도심 활성화 조례를 통해 원도심 공동화 현상 방지 와 원도심 활성화, 근대역사문화의 보존 및 활용을 추구하고 이후 지속적으로 원도심의 근대문 화역사를 보존하기 위한 도시재생사업을 추진중이다. 종합해보면 군산시의 주거지 공간구조는 일제 강점기 도시계획에 의해 형성된 일본인거류지와 자연발생적으로 형성된 한국인주거지로 부터 1970 1990년대까지의 국가주도의 산업단지 조성과 함께 군산항을 중심으로 내륙쪽으로 지속적으로 확장되었다고 하겠다. 건축물대장으로 군산시의 주택분포의 변화를 정리하였다(그 림4, 그림5참조). 1960 년까지는 일제 강점기 형성된 군산항(조계지)을 중심으로 주택들이 신축 


\section{<그림 3> 고지도로 본 군산시 공간구조 변화(1931 2006년)}

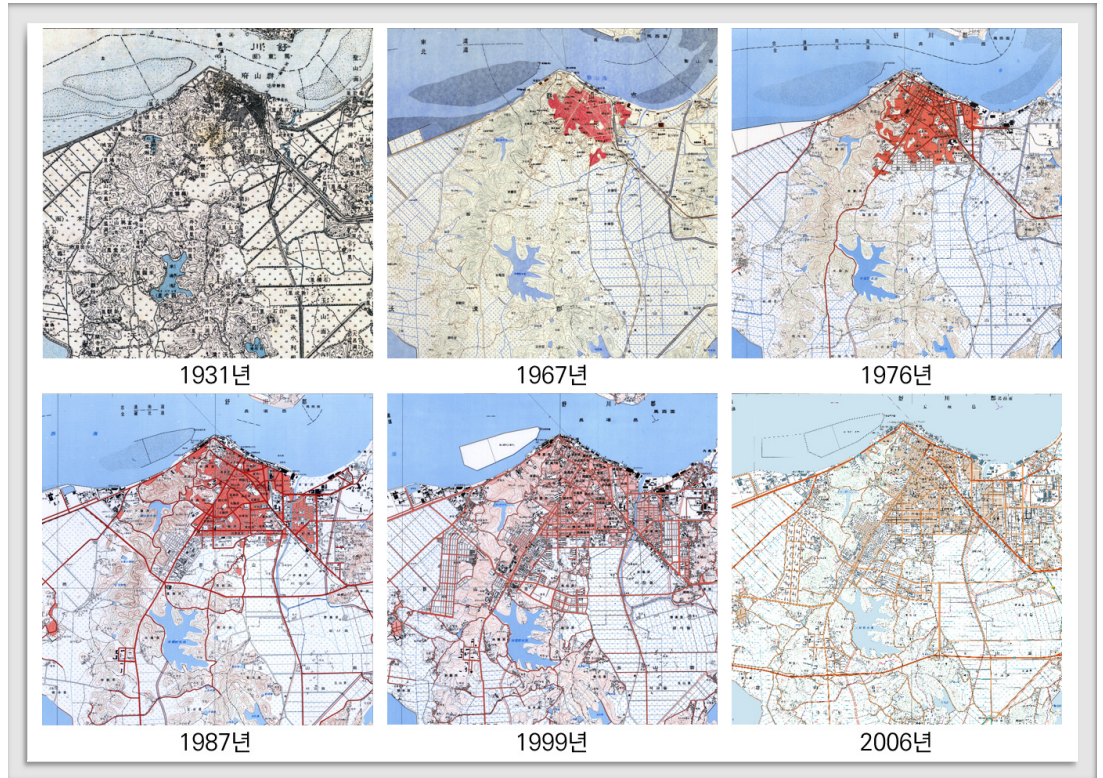

출처: 국토지리정보원 공간정보받기(http://map.ngii.go.kr/ms/map/NlipMap.do\#)

(파란색표기)되었음을 알 수 있다. 이후 1980년대에도 여전히 군산항을 중심으로 산업단지가 조성되는 해안과 반대되는 내륙방향으로 신축이 증가하고 2010년 이후에는 산발적으로 주택신 축이 일어나는 모습을 볼 있다. 면적대비 주택증가수로 본 군산시 주거지형성의 시계열변화를 보면 주택분포의 추이는 60 년대 군산항을 중심으로 중앙로, 평화동, 개복동, 영화동에서 주택 신축이 활발하였다. 80년대 산업단지 조성과 함께 남서쪽으로 오룡동, 삼학동까지 주택신축이 증가하고 90년대에는 군산항의 북동쪽의 성산면, 나포면까지 주택신축이 증가한다. 2000년대 이후는 군산시 전역으로 면적대비 주택신축이 일어나고 있음을 볼 수 있는데 다만 도심의 주택 신축(파란색표기)은 많지 않음을 알 수 있다.

\section{<그림 4> 군산시 시계열별 주택분포 현황비교}

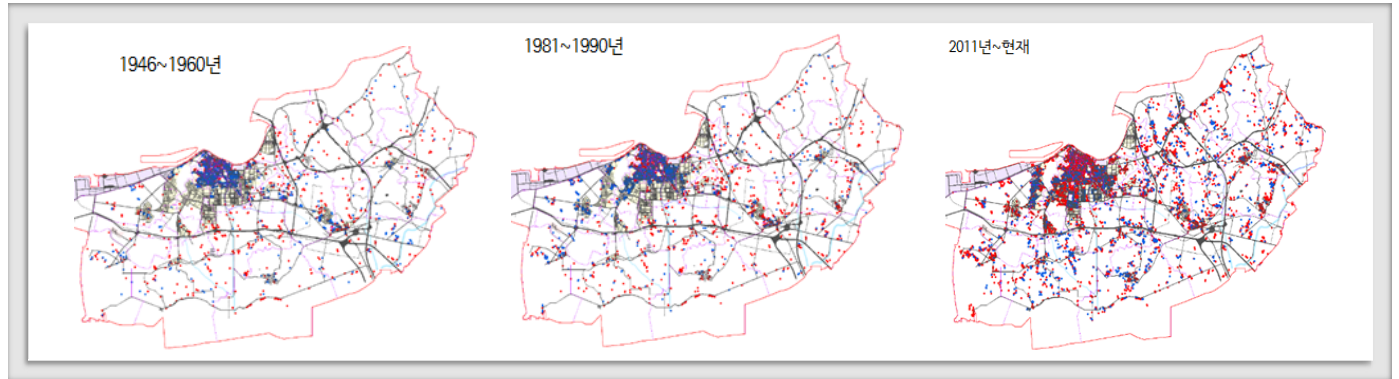


<그림 5> 면적대비 주택증가수로 본 군산시 주거지형성의 시계열적 변화

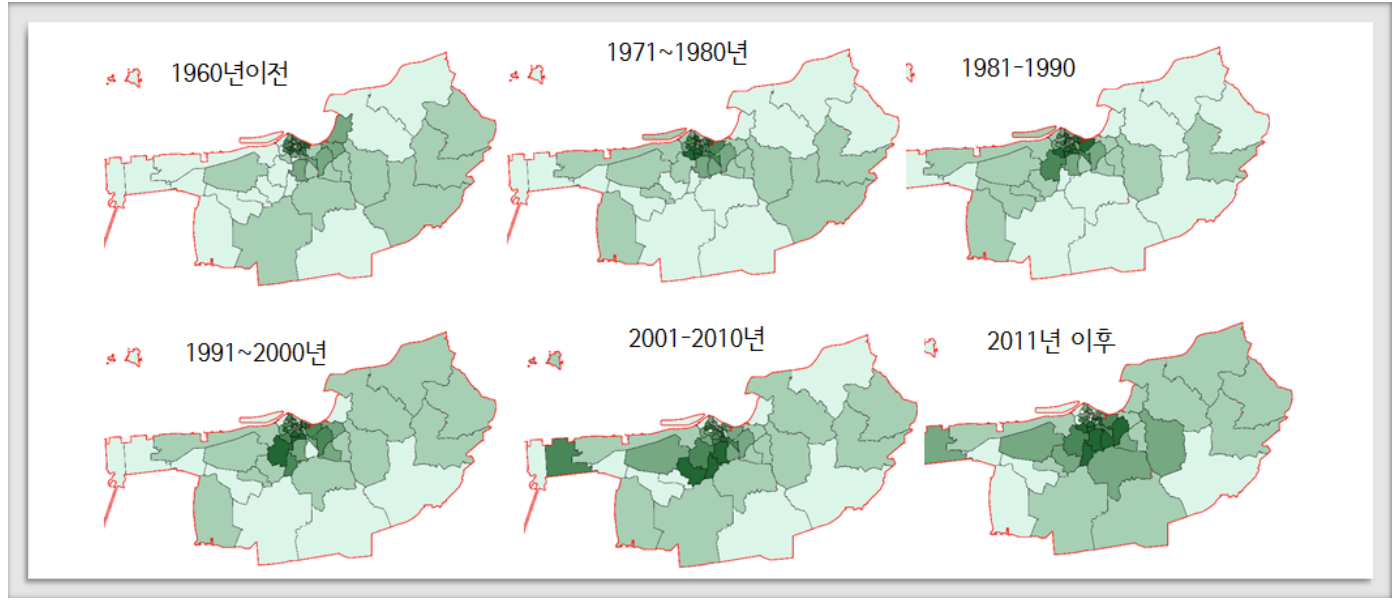

<그림 6> 군산시 주거지형성의 시계열적 변화

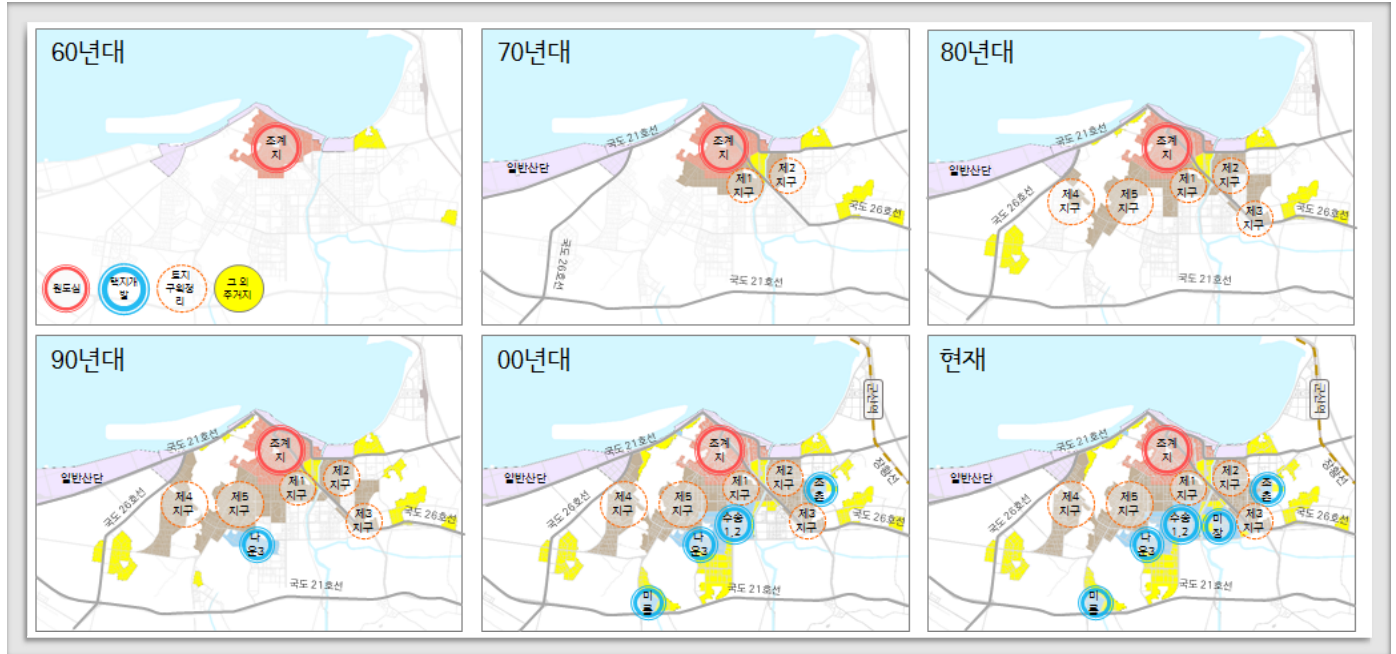

앞에서 다룬 건축물대장과 고지도를 통해 본 주거지형성의 공간구조를 사업단위로 구분하여 시계열로 나타낸 것이 〈그림6〉이다. 군산시 주거지형성의 시계열적 변화는 군산항의 조계지에 서 시작하여 일제 강점기 토지구획정리사업을 통한 1 차 확장, 1980 년대 정부의 정책사업인 국 가산업단지개발과 함께 이를 주변으로 한 주거지의 남쪽으로의 확장, 1990 년대 이후로는 대규 모 택지개발사업으로 주거지가 도시 전역으로 방사형으로 공급되고 있는 중이다. 


\section{2. 목포의 주거지형성과정 변화}

목포시의 1960년대부터 최근까지 제작된 지도를 통하여 공간구조 변화를 살펴보았다(그림 7 참조).

\section{<그림 7> 고지도로 본 목포시 공간구조 변화(1963 2016년)}

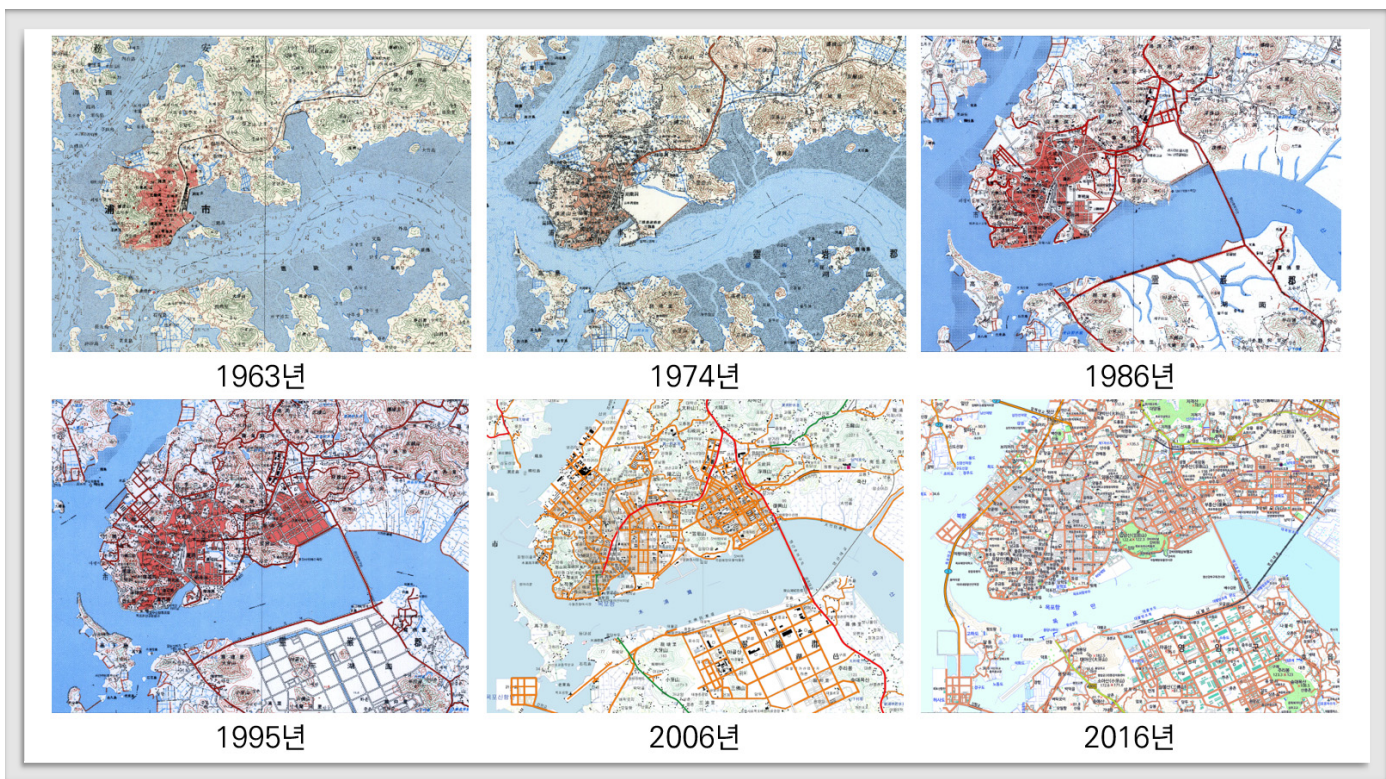

출처: 국토지리정보원 공간정보받기(http://map.ngii.go.kr/ms/map/NlipMap.do\#)

목포지역은 예부터 광주, 나주, 능주 등 시장이 형성된 내륙과 통하는 길목으로 중국, 일본을 잇는 삼각항로의 중심에 위치하여 지리적, 경제적 이유로 1897년 목포항을 개항하였고, 1910 년 목포부(木浦府)로 개칭하였다. 1914년 호남선 철도가 개통되었고, 그해 무안군 부내면이 목 포부에 편입되었다. 1932년 무안군 일부를 통합하여 인구가 6만인 전국 6대 도시의 하나가 되 었다. 목포의 구시가지는 크게 두 지역으로 구분되는 데, 하나는 개항 이전부터 조선인들이 거 주했던 지역이고, 다른 하나는 목포의 개항과 역사를 같이하는 각국공동거류지가 형성된 지역 으로 매립을 통해 대부분의 지역이 조성되었다. 1975년 용당동, 산정동 일대에 토지구획정리 사업(제1지구)을 착공하여 1984년에 완공되었으며, 목포시 구도심의 북쪽으로 북항과 인접하 여 죽산지구 $\left(581,821 \mathrm{~m}^{2}\right)$ 와 용해지구 $\left(211,571 \mathrm{~m}^{2}\right)$ 가 1980년에 사업계획이 수립되어 1981년 착공되었다. 1980년대 간척을 통한 택지조성(남해지구)으로 대규모 주택단지 및 산업단지가 조성되어 중요한 무역항으로 부상하였다. 
목포의 기존 시가지 동쪽으로 하당신도시를 1988년 목포신도시개발 기본계획수립을 거쳐 1989년 택지개발예정지구로 지정하고 1991년 1995년 공사 시행 및 준공하였다. 목포시 외곽지 역에서 1990년대부터 2000년 초까지 택지개발사업이 활발히 추진되어 왔다. 목포시 남쪽 전라남 도 영암군 삼호읍 일대에 대불산업단지가 1996년 12월 완공되어 기업입주가 시작되었다. 2000 년대 서해안 고속도로, 호남선의 복선화 및 고속철화, 무안 국제공항 등이 건설되면서 도시가 성장 하였으며, 2003 년 옥암지구, 남악지구(무안군)의 개발로 1.3 만여 가구가 공급되면서 원도심과 구 시가지의 인구유출이 초래되었다. 현재 개항 이후 줄곧 목포의 중심지 역할을 했던 목포역 주변의 상업·업무기능이 쇠퇴하고 신도시인 하당지역으로 이전하여 도심의 기능을 수행하고 있다.

목포시의 건축물 대장을 동단위 시계열적으로 적용하여 〈그림8〉, 〈그림9〉로 나타내었다. 목 포시의 주택분포 추이는 1960 70년대 원도심 중심으로 주택공급이 지속적으로 일어나고 있으 며, 1970년대에는 산정, 용당동 일대 택지조성으로 시가지가 확장되면서 주택공급이 이 일대 에 급증하였다. 1980년대에는 간척사업에 의한 남해지구 시가지조성으로 원도심 확장이 되는 형태로 시가지가 개발되고, 북항개발이 이루어지면서 구도심과 인접한 외곽지역에 신규 주택공 급이 많이 이루어진 것으로 나타났다. 1990년대에는 원도심과 떨어진 외곽지역에 대규모 신도 시 개발(하당지구)과 북항 인근지역에 세라믹 산단 개발로 시가지가 크게 확장되었으며, 외곽신 도시 건설에 의한 주택공급의 증가와 더불어 원도심권에서도 주택공급은 지속적으로 이루어진 것으로 나타났다. 2000년대 이후 원도심권의 신규 주택공급은 급격히 감소한 것으로 나타났으 며, 하당지구의 신규 주택건설은 지속되었다. 새롭게 남악신도시, 대양산단 개발이 이루어지면 서 목포시의 개발가용지는 대부분 소진된 것으로 나타났다.

\section{<그림 8> 목포시 시계열별 주택분포 현황비교}

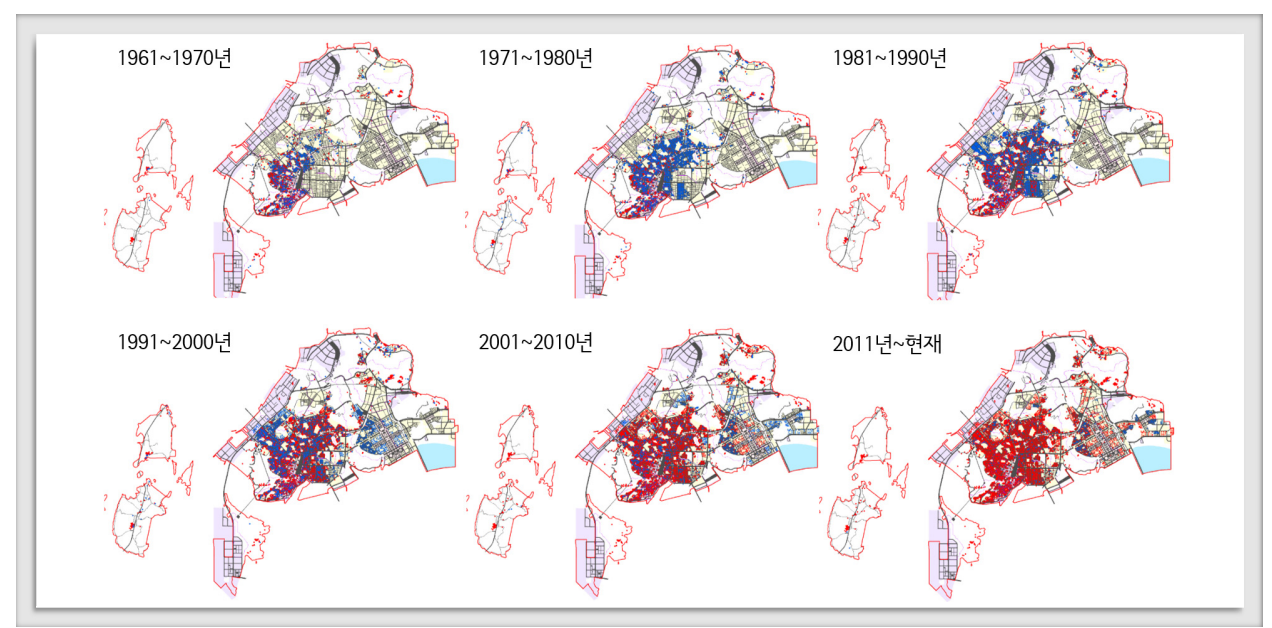




\section{<그림 9> 면적대비 주택증가수로 본 목포시 주거지형성의 시계열적 변화}

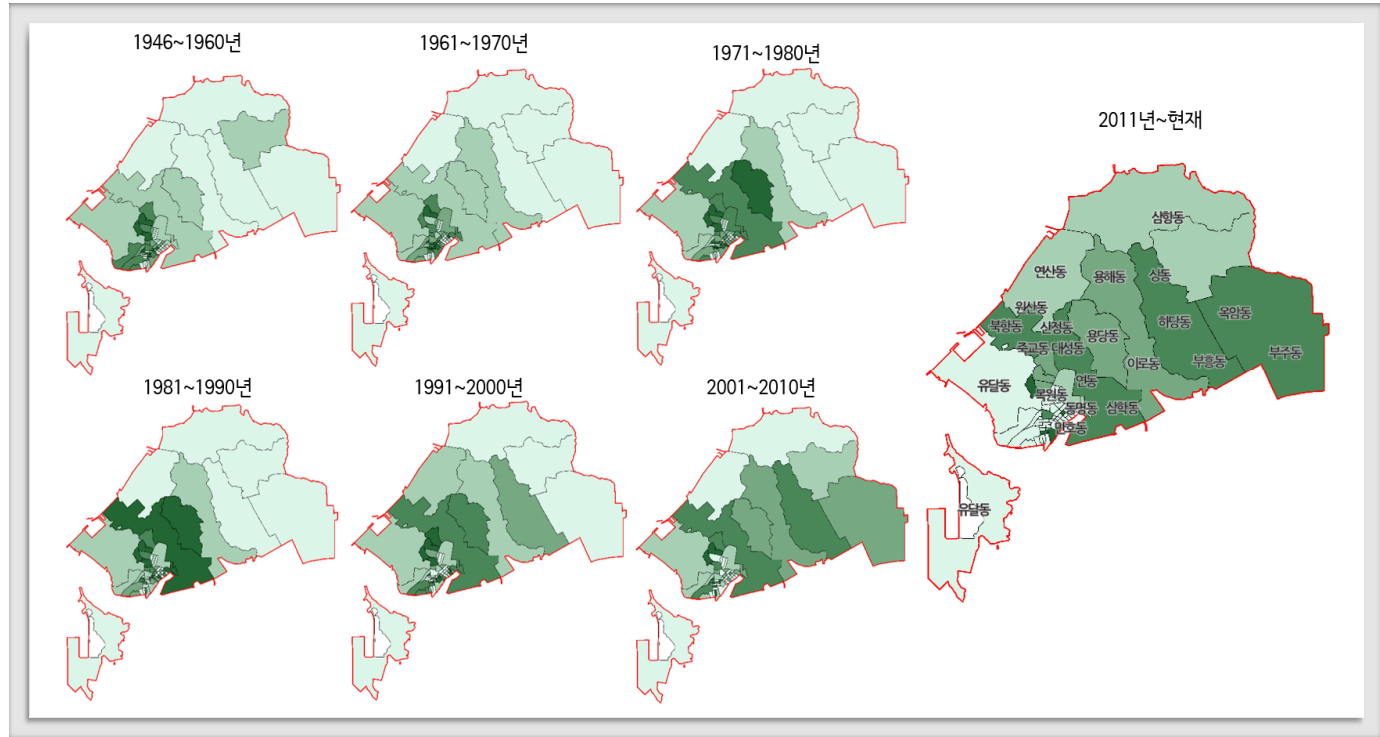

앞에서 목포의 주거지 공간구조를 고지도와 건축물대장을 통해 살펴보았다. 〈그림10〉은 이 를 종합하여 주거지형성의 공간구조를 나타낸 것으로 1960년대는 목포항의 조개지에 국한하여 주거지가 형성된 도시에서 1970년대이후 택지개발사업을 통해 주거지가 형성되기 시작하였다. 2000년대 이후 전남도청의 남악신도시 이전으로 주거지공간은 목포항을 기준으로 동쪽으로 넓 게 확장되어 가는 형태를 보이고 있다.

\section{<그림 10> 목포시 주거지형성의 시계열적 변화}

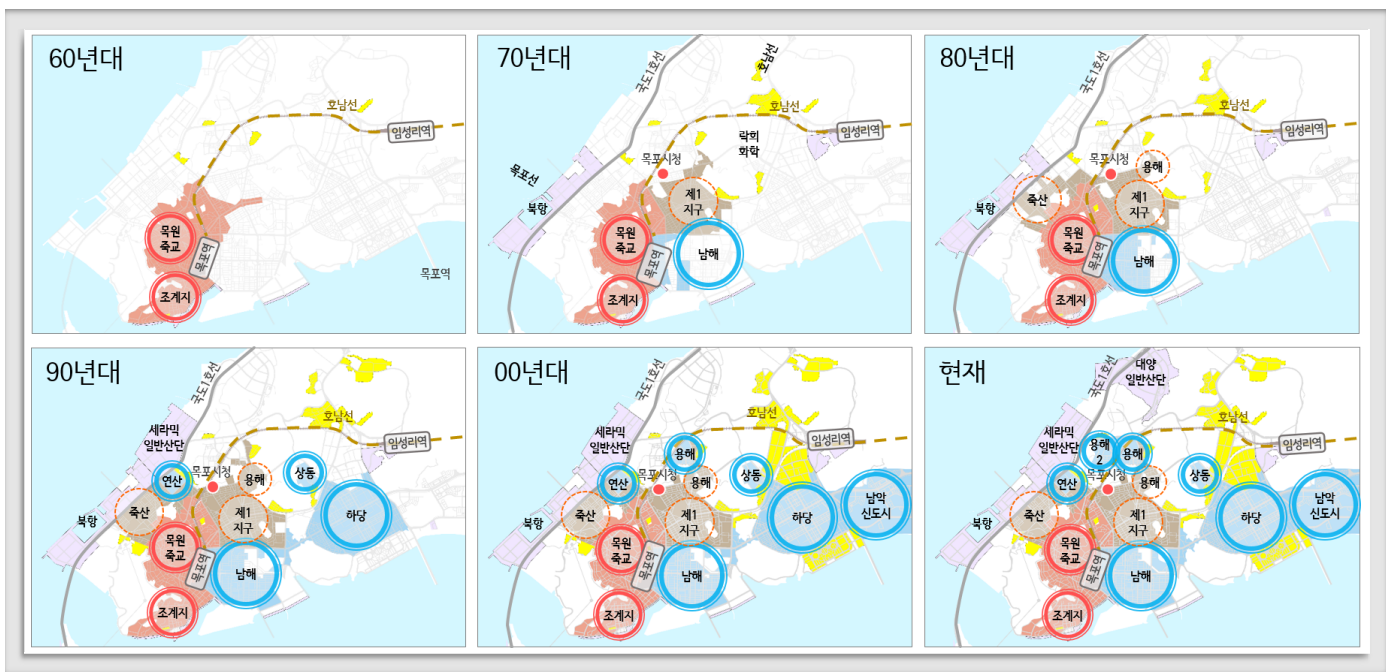




\section{IV. 지방중소도시 주거지 유형}

\section{1. 군산시의 주거지유형화 및 유형별 특성}

군산시의 주거지유형은 기존지역에서 4 가지유형, 신규지역에서 5개 유형이 조사되었다. 〈그 림11>은 군산시의 주거지유형을 공간에 표현한 것이다.

<그림 11> 군산시시 주거지유형화 구분

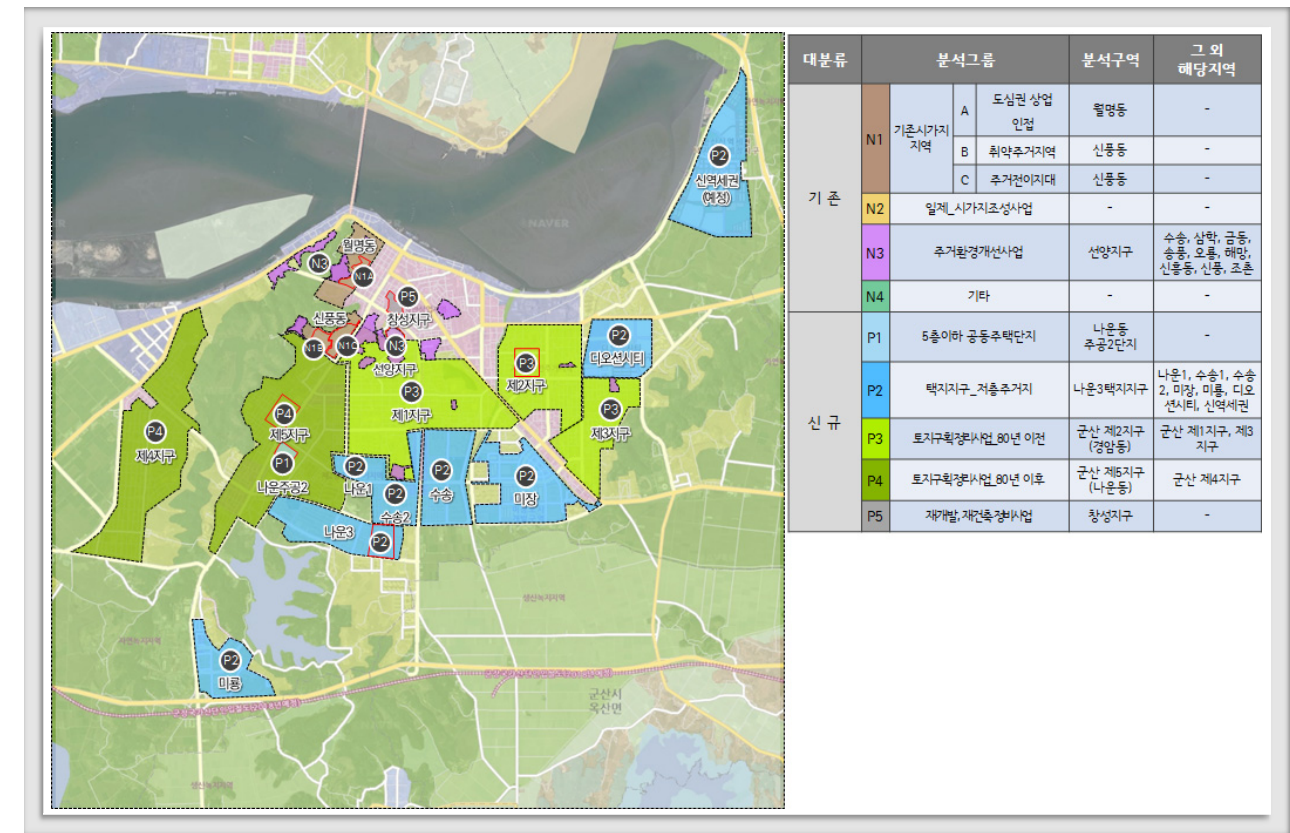

기존지역은 도심권 상업인접지역, 취약주거지역, 주거전이지역, 주거환경개선사업지역이다. 군산시는 일제 강점기 조계지로 형성되었으나 주거지의 많은 부분이 상업지역으로 지정되어 주 거지유형화에서는 제외되었다. 신규지역은 택지개발사업중 90년 이전의 주택단지유형, 택지개 발사업, 토지구획정리사업(80년 이전, 이후), 재개발사업이 나타났다. 도심권 상업인접 지역은 월명동 상업지역에 인접한 곳으로 일제 강점기 시가지조성사업을 시행한 곳을 일부 포함하고 있는 지역이다. 상업지역에 인접하고 있으나 $99 \%$ 저층의 단독주택들이 위치하고 있고 목조건축 물이 가장 많고 조적조, 철근콘크리트순서이다. 주택의 노후도는 $79.5 \%$ 로 높은 편이고 필지면 적별 비율을 보면 소필지( $60 \mathrm{~m}^{2}$ 미만)비율이 $31.7 \%, 60 \sim 140 \mathrm{~m}^{2}$ 비율이 $37.9 \%$ 로 높았다. 그리고 
남쪽으로는 자연발생적으로 형성된 주거지로 도로체계가 비정형화되어 있어 특히 소필지와 맹 지들이 많이 분포하고 있다. 특히 이 지역 주변으로 최근 도시재생사업을 진행하고 있어 1층이 카페나 상가로 전환되는 곳도 많이 관찰되고 있고 근생비율이 $23.5 \%$ 로 높은 편이다. 다만 군데 군데 빈집이나 빈점포들, 공사중인 곳도 많다.

취약주거지역으로는 신풍동일대를 선정하였는데 이 지역은 정비사업을 수행하여 공원화한 지역에 인접한 곳으로 별도의 정비사업은 시행되지 않은 지역이다. 도심공원에 면하는 경사지 에 형성된 곳으로 일부는 급경사지에 주택들이 위치하고 있다. 전체적인 건축물의 노후도(30년

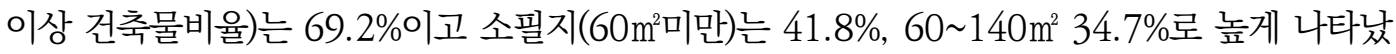
다. 또한 도로체계가 정형화되어 있지 않고 일부도로만 도시계획도로로 조성되어 주거지내 소 로와의 격차가 크게 나고 있다. 빈집도 10 동정도 있고 10 년이내 신축건물도 적은 편이다. 다만 도심공원에 인접하여 공영주차장이 4개소가 있고 경로당, 도서관, 공공청사들은 반경 $500 \mathrm{~m}$ 이 내에 위치하고 있다. 주거환경개선사업을 시행한 선양동은 2004년 사업을 완료한 지역으로 도 로와 주차장을 정비한 곳이다. 도로는 마을내부 2곳에 도시계획도로를 신설하였으나 소필지, 맹지에 있는 주택들의 접근로는 여전히 어려운 상황이다. 소필지 비율이 40.9\%로 매우 높았고 30 년 이상 노후 건축물비율도 $90 \%$ 로 정비 사업을 시행하였으나 개별건축물에 대한 정비는 이 루어지지 않은 실정이다. 상업지역인접으로 내부에 근생 비율은 높지 않으나 인근 공영주차장 은 13 개소로 설치되어 있었다.

택지개발사업은 1990년 이전과 1990년 이후로 구분하였는데 먼저 1990년 이전에 준공한 공동주택단지(P1)는 1981년 준공으로 전체적으로 건축물의 노후화가 많이 진행되고 있으며 지 속적으로 재건축논의가 되고 있는 중이다. 주변에 저층주거지가 형성되어있고 시장, 공공청사, 복지시설 등은 잘 갖추어져있으나 단지의 노후화, 단지 내 주차시설 부족, 일부공가 등의 문제 가 예상된다. 1990년 이후의 택지지구는 1996년 준공된 나운지구로 필지규모나 기반시설은 양호하고 공공시설도 잘 갖추어져 있는 편이다. 토지구획정리사업은 1980년 이전과 1980년 이후로 유형화하였는데 1980년이후 지역인 나운동 일대는 택지개발사업지역과 필지체계는 유 사하나 30년 이상 주택노후비율 $15.9 \%, 60 ~ 140 \mathrm{~m}^{2}$ 필지비율 $6.5 \%$ 정도, 극히 일부지역 맹지발 생 등 일부 지역에 개선이 필요한 정도이다. 1980년 이후 토지구획정리사업지역은 경암동 일 원으로 저층(1 2층 단독주택중심) 건축물의 노후도 비율은 $80 \%$ 로 높았으나 60 $140 \mathrm{~m}^{2}$ 필지비 율이 $8.7 \%$ 로 필지규모가 작지 않아 최근 주택신축도 증가하고 있고 지붕수리사업도 많이 진행 된 것으로 추정된다. 또한 블록별 도로와 도로사이의 골목길들이 있으나 맹지가 발생하는 곳은 극히 드물어 거주의 불편함은 크게 발생하지 않고 있었다. 그리고 토지구획정리사업이기에 공 
영주차장, 공원, 학교, 공공청사, 경로당 등도 반경 $500 \mathrm{~m}$ 이내에 설치되어 있었다. 재건축사업 은 2007년 준공한 창성동으로 주변의 저층주거지에 둘러싸인 곳이다. 신축 공동주택단지로 기 반시설이나 단지 내 부대시설들이 잘 갖추어져있으나 주변의 저층주택과의 조화측면에서 노후 화된 주변주택과의 이질감이 크게 나타났다.

\section{2. 목포시의 주거지 유형화 및 유형별 특성}

목포시의 주거지유형은 기존지역에서 5가지 유형, 신규지역에서 5 가지 유형으로 총 10 개 유 형이 조사되었다. 〈그림12〉는 목포시의 주거지를 유형별로 표시한 것이다. 기존지역은 도심상 업 인접 주거지 유형(N1A) 및 일반주거지역 유형 $(\mathrm{N} 1 \mathrm{~B}, \mathrm{C})$, 일제 시가지조성사업(N2)과 기성 시가지내 주거환경개선사업에 의해 기반이 정비된 주거지 유형(N3)이 조사되었다. 신규지역에 서는 저층 공동주택단지(P1), 택지지구 내 저층주거지(P2), 80년대 이전 토지구획정리사업 (P3), 80년대 이후 토지구획정리사업지구(P4), 주택재개발에 의한 공동주택단지(P5) 유형이 조 사되었다. 기존시가지 지역에서 도심권 상업지역에 인접한 주거지역은 대부분 근대 이전에 형 성되었으며 이 중에 목포역 서쪽의 경사지역(축후동)에 위치한 지역에 대해서 실태조사한 내용 을 살펴보면, 주택 노후도는 $81.1 \%$, 소필지 비율은 $81.1 \%, 10$ 년 이내 신축주택이 $2.1 \%$ 로 노 후화가 많이 진행되었으며 일부 주택은 지붕공사 등의 주택개량이 이루어지고 있었다. 소필지 로 인한 막다른 골목이 존재하고 있으며, 지역 내 일부 지역 만 도시가스가 공급되고 있어 지역 내 인구는 점차 감소하고 있는 추세이다. 대상지역에는 도로 확폭 등의 기반시설 확충이 필요하 고, 노후건축물 정비 등 기본적인 주거환경 개선이 시급한 실정으로 파악되었다.

취약주거지역에 대하여 산정동 일대에 대해서 실태조사한 내용을 살펴보면, 기존시가지의 상 업지역에 인접한 구릉지역에 자연발생적으로 형성된 주거지역으로 산정언덕로를 제외한 대부 분의 내부 도로는 폭원이 협소(1 3m)하여 차량 접근이 불가능하였다. 30년 이상 건축물비율 은 $72.2 \%$, 소필지 비율은 $29.5 \%, 4 \mathrm{~m}$ 이상 접도율은 $55.3 \%$, 슬레이트 지붕은 $10 \%$ 로 매우 열 악한 주거환경으로 형성되어 있었다. 하수시설이 노후화되어 다수의 민원이 발생하고 있으며, 물리적 환경을 전반적으로 개선시킬 수 있는 사업이 필요한 것으로 파악되었다. 


\section{<그림 12> 목포시 주거지유형화 구분}

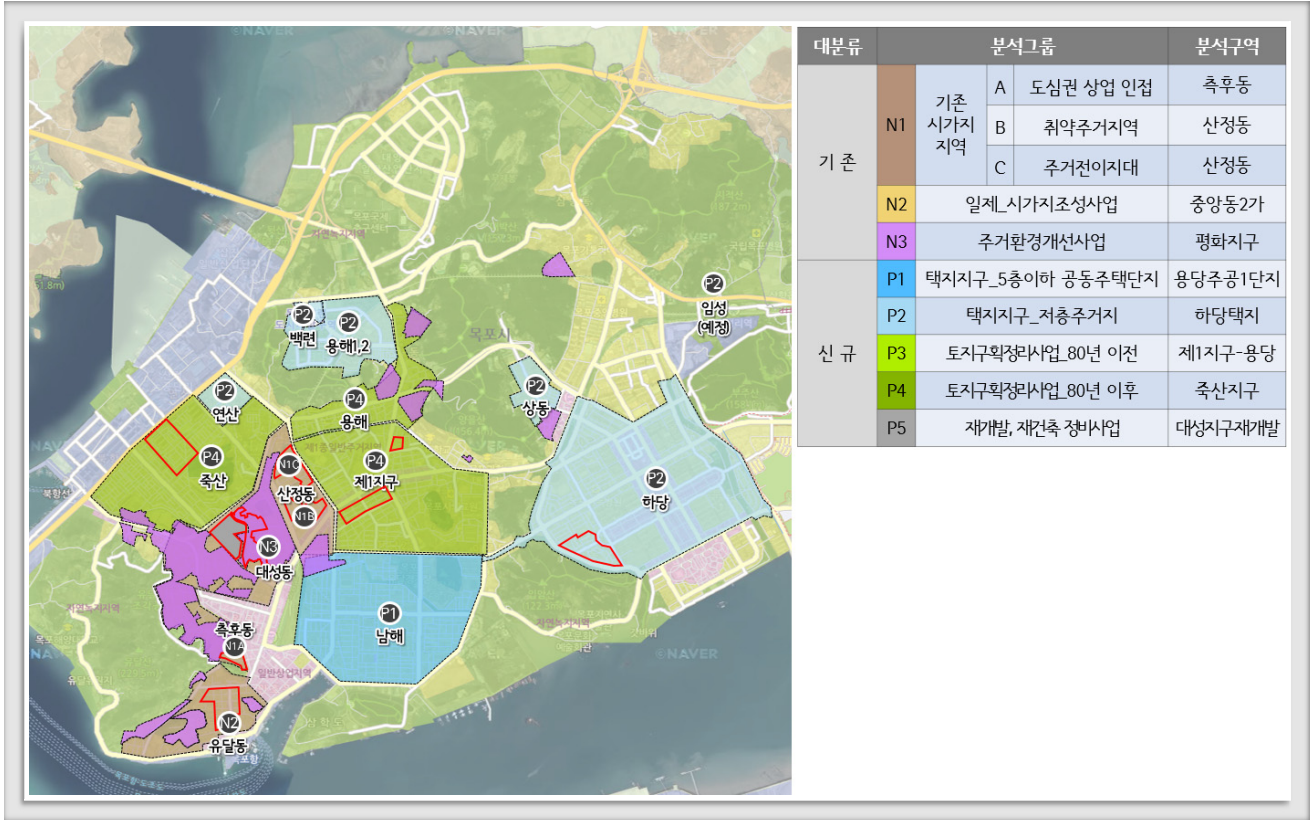

기존시가지 지역 중에서 주거전이지역에 대하여 산정동 일대에 대해서 실태조사한 내용을 살 펴보면, 원도심의 외곽지역으로 산정동 주거환경개선지구와 이리마동 택지개발지구 사이에 위 치하였으며 구역 내 일부지역은 60 70년대 토지구획정리사업이 시행되어 형성된 주거지역으 로 추정되며 가로환경이 북측 주거지에 비해 양호하였다. 30 년 이상 건축물비율은 $81.0 \%$, 소 필지 비율은 $29.0 \%, 4 \mathrm{~m}$ 이상 접도율은 $71.2 \%$, 슬레이트 지붕은 $9.4 \%$ 로 노후한 주거지역으로 조사되었다. 주변지역 개발은 비교적 활발하나 대상지 내 주택의 개량.정비는 정체되어 있는 상황으로 지역 일부는 좁은 골목의 정비, 주차환경 개선, 도시가스 인입, 노후건축물 정비 등이 시급한 실정으로 파악되었다.

일제시가지조성사업으로 형성된 주거지역 중에 중앙동 2 가 일대에 대해서 실태조사한 내용 을 살펴보면, 대상지역에는 일제강점기 조성된 일본식 가옥이 다수(21.1\%) 존재하며, 근대역 사·문화유산이 주변지역을 포함하여 다수 분포하고 있다. 1 층은 상가, 2 층은 주택이 결합된 상 가주택이 많아 근린생활시설 비율이 높고, 주택의 노후도는 $85.8 \%$, 소필지 비율은 $48.3 \%, 4 \mathrm{~m}$ 이상 접도율은 $71.2 \%$, 슬레이트 지붕은 $7.5 \%$ 로 노후한 주거지이다. $12 \mathrm{~m}$ 폭원의 도로망에 의 하여 격자형으로 블록(약 $70 \mathrm{~m} \times 60 \mathrm{~m})$ 이 형성되어 있으며, 대체로 필지규모가 양호한 편이나 일부 지역에서는 필지가 분화되어 과소필지 규모도 다수 존재하고 있다. 도로가 넓어 기본적인 
주거환경이 쾌적한 편이며, 기존 원도심의 상업, 생활서비스·인프라의 접근성이 매우 높은 편 이다. 시에서 추진 중인 근대문화유산거리 등 관광객 유입을 통한 지역활성화를 도모하는 사업 추진이 필요한 것으로 파악되었다.

주거환경개선사업이 시행되었던 주거지역 중에 대하여 대성동 일대에 대해서 실태조사한 내 용을 살펴보면, 해당 지역은 한국전쟁 후 피난민이 모여들어 형성된 원도심 외곽의 서민주거지 역으로 인접한 대성지구(천년나무아파트)와 함께 정비구역으로 지정되어 주택재개발을 추진하 였으나 주민들의 이해관계로 무산되었다. 4층 이하 주택이 $99.6 \%$ 이며, 주택의 노후도는 $75.9 \%$, 소필지 비율은 $33.6 \%, 4 \mathrm{~m}$ 이상 접도율은 $30.2 \%$, 슬레이트 지붕 $17.0 \%$ 로 매우 열악한 노후불량주거지이다. 주거환경개선사업에 의해 개설된 도로 외에 대부분 주택이 도로에 접하지 않아 차량진입이 불가능하다. 대상지 내부에는 생활편의시설이 거의 없으며, 인근 재개발사업 구역 내에 다수 입지하고 있다. 주거환경개선사업(2007년)으로 도로 등 기반시설이 공급되었 지만, 도로 인접지역 외는 주거환경 개선의 효과는 미미한 실정이다.

신규로 조성된 지역에서 80년대 이전 토지구획정리사업이 시행되었던 주거지역 중에서 70 년대 용당지구에 대해서 실태조사한 내용을 살펴보면, 토지구획정리사업을 통하여 가로 개선 및 토지 정비가 이루어져 있으며 내부 도로(8 10m)는 격자형으로 조성되어 있다. 주택은 4층 이하 저층이 $99.7 \%$ 이며, 30 년 이상 건축물비율이 $69.5 \%$, 소필지 비율은 $4.5 \%, 4 \mathrm{~m}$ 이상 접도 율은 $71.2 \%$ 로 원도심에 비해서는 주거환경이 양호한 노후주거지로 나타났다. 이 지역에 대해 서는 일부 도로의 확폭과 함께 주차장, 공원 등 기반시설 확대가 필요한 것으로 파악되었다. 80 년대 이후 토지구획정리사업이 시행되었던 주거지역 중에서 1988년 죽산 토지구획정리사업을 통하여 조성된 산정동 일대에 대해서 실태조사한 내용을 살펴보면, 대상지 북측은 아파트단지 (최고 15층)가 조성되어 있으며 남측은 주택 및 근린생활시설이 입지하고 있다. 비교적 최근에 조성된 주거지역으로 30년이상 건축물비율은 23.1\%로 낮게 나타났으며, $4 \mathrm{~m}$ 이상 접도율은 $99.0 \%$, 소필지 비율은 $0 \%$ 로 매우 양호한 주거지로 나타났다. 도로, 공원 등의 기반시설은 매우 양호하지만, 주차장이 일부 부족한 것으로 판단되었다.

5층 이하 공동주택단지 중에서 용당동 토지구획정리사업구역 내에 입지한 5층 아파트단지에 대해서 실태조사한 내용을 살펴보면, 아파트 전체가 단일 필지이며 도시계획도로로 둘러싸여 있 으며 1977년 준공되어 30년 이상 경과된 5층 공동주택 9개 동과 관리동(1층), 상가동(2층) 건물 로 조성되어 있다. 일정 규모의 공동주택단지이지만 도시가스가 인입되지 않아 LPG를 사용하고 있으며, 거주민들은 주로 취약계층으로 주요 주거사유로는 저렴한 주거비를 들고 있었다. 대상 지의 대상지 내외에는 경로당(7), 요양원(2), 유치원(3), 어린이집(3), 지역아동센터(1) 등이 있어 
노인 복지 및 보육환경이 양호하고, 인접하여 교육시설들이 다수 입지하여 교육환경도 양호한 것으로 나타났다. 노후 공동주택에 대한 성능개선 및 정비가 필요한 것으로 파악되었다.

1990년대 택지개발지구에 의해 조성된 지역 중에서 저층주택용지로 공급된 지역에 대해서 실태조사한 내용을 살펴보면, 비교적 최근 택지지구로 조성되어 주거환경이 쾌적하고 격자형 도로망이 잘 형성되어 있으며 도로나 필지의 형태의 매우 양호하고 기반시설이 충분히 공급되 어 타 지역에 비해 높은 지가를 형성하고 있다. 주택은 대부분 3 4층(56.2\%)이 가장 많으며 4 층 이하 저층이 $97.0 \%$ 이며, 필지면적은 $140 \mathrm{~m}^{2}$ 이상이 $98.1 \%$, 도시가스는 $100 \%$ 로 공급되고 있 다. 준주거지역에는 주거·상업이 복합된 중층 건물이 입지하고 있으며, 근생과 주택이 복합된 상가주택이 많아 상가 이용 차량 등에 의해 주차 문제가 나타나고 있다.

주택재개발사업구역에 대하여 실태조사한 내용을 살펴보면, 주택재개발 이전에는 6.25이후 피난민들이 정착한 쪽방촌이 형성된 일대였으며 2015년 정비사업을 추진하여 아파트단지로 조 성되었다. 재개발전에는 주로 고령층이 거주하였으나, 재개발 이후에 아파트가 조성되면서 젊 은 계층이 유입되었다. 단지 내에는 근린상가 1 개 동이 있으며, 아파트단지와 인접하여 학교 (4), 유치원(2), 어린이집(7), 지역아동센터(1), 경로당(6), 재가복지센터(1), 어린이공원(1) 등이 위치하여 보육환경 및 교육환경은 우수한 것으로 파악되었다.

\section{3. 주거지유형별 특성 비교}

군산과 목포의 주거지유형은 아래〈표1〉과 같이 9개 유형이 모두 나타나고 있었다.

\section{<표 1> 도시별_유형별 분석 개요}

\begin{tabular}{c|c|c|c|c|c|c|c|c|c}
\hline \multirow{2}{*}{ 구분 } & 도심상업 & 취약주거 & 전이지역 & 주환사업 & $\begin{array}{c}\text { 5층 } \\
\text { 공동주택 }\end{array}$ & 택지지구 & $\begin{array}{c}\text { 토지구획 } \\
\text { 80이전 }\end{array}$ & $\begin{array}{c}\text { 토지구획 } \\
\text { 80년이후 }\end{array}$ & 재건축 \\
\hline 군산 & $\bigcirc$ & $\bigcirc$ & & $\bigcirc$ & $\bigcirc$ & $\bigcirc$ & $\bigcirc$ & $\bigcirc$ & $\bigcirc$ \\
\hline 목포 & $\bigcirc$ & $\bigcirc$ & $\bigcirc$ & $\bigcirc$ & $\bigcirc$ & $\bigcirc$ & $\bigcirc$ & $\bigcirc$ & $\bigcirc$ \\
\hline
\end{tabular}

〈표2〉는 주거지유형을 기존지역과 신규지역으로 크게 구분했을 때 각 유형별 쇠퇴, 활력, 생 활편의성을 중심으로 유형별 특성을 정리하였다. 유형별로 해당지표에 대해 평균값을 기준으로 각 유형별로 상대적인 비교로 매우불량·낮음 $(X X)$, 불량 $(X)$, 보통 $(\triangle)$, 양호 $(\bigcirc)$, 매우양호·높음 $(\bigcirc)$ 로 표기하였다. 각 유형별로 기존지역과 신규지역에서 가장 차이가 나는 지표는 쇠퇴도의 
건축물노후도와 소필지 비율로 상업인접주거지유형과 토지구획사업(80년 이전), 저층공동주택 (90년 이전)의 건축물노후도의 경우는 재생사업의 기준을 초과하고 있다.

소필지 비율은 건축이 어려운 $60 \mathrm{~m}^{2}$ 미만, $60 ~ 140 \mathrm{~m}^{2}$ 비율이 높은 유형은 상업인접주거지유형 이 가장 열악하고 다음이 일반주거지유형, 그리고 토지구획정리사업(80년 이전)유형이다. 기존 지역 내 이 세 가지 주거지유형에서 가장 시급한 것은 건축물의 쇠퇴와 필지체계의 개선으로 뽑 을 수 있다. 소필지 비율과 건축물노후화는 빈집(공폐가)의 숫자를 늘리고 좁은골목과 소필지로 인해 건축물의 신축도 어렵게 하고 있는 근본적인 이유이기도 하다. 기존지역의 빈집은 주로 저 층의 노후화된 주택으로 공실로 방치되는 경우, 쓰레기, 악취로 미관을 해치는 등 정주환경의 질을 악화시키고 있다. 신규지역의 저층공동주택단지유형, 재건축유형, 택지개발사업유형의 가 장 큰 차이점은 주거지의 규모로 저층공동주택단지와 재건축유형은 중규모의 주거단지이고 택 지개발사업유형은 대규모 복합개발로 주거지뿐만 아니라 상업, 업무 등의 용도로 포함하고 있다. 그리고 저층공동주택단지와 재건축의 차이점은 건축물의 노후도가 가장 크고 재건축사업유형은 신축건축물비율도 상대적으로 높다. 주거지재생이 필요한 유형은 이 중에서 저층공동주택단지

<표 2> 주거지유형별 쇠퇴도 활력도 생활편의성 특성비교

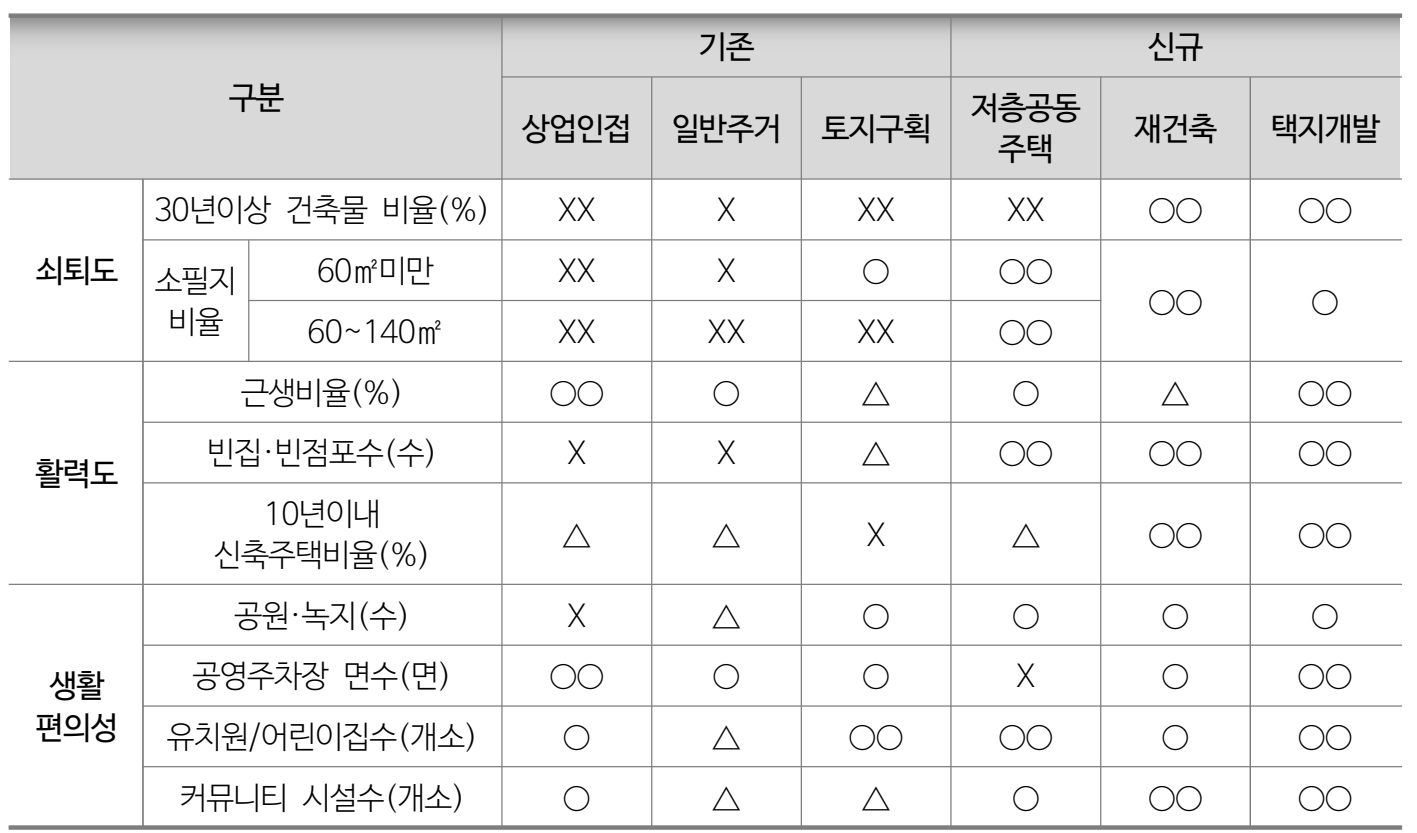

* 소필지 비율은 $20 \%$ 이상 매우불량, $10 \%$ 대 불량, $10 \%$ 미만 양호로 표기, 근생비율 $20 \%$ 이상 매우 높음, $10 \%$ 대 높음, $10 \%$ 미만 보통, 빈집수는 전체건축물의 $2 \%$ 이상이면 불량, 신축주택비율은 $20 \%$ 이상 매우양호, $5-10 \%$ 이하 보통, $5 \%$ 미만 불량, 생활편의성지표는 6 개유형별 순위로 표기 
(90년 이전)로 본 연구 조사대상 지역의 건축물대장을 분석한 결과 목포 23 개단지, 군산 32 개 단지로 조사되었다. 노후화가 심한 저층공동주택단지가 원도심에 위치하고 있기 때문에 이에 대한 재생방안도 검토가 필요하다고 생각된다. 주거지유형별 생활편의성에서 특징적인 점은 택 지개발사업, 재건축사업유형의 경우 건축물 내 혹은 단지 내 주차장이 있어서 공용주차장이 기 존지역보다 상대적으로 적었고 기존지역 내에서는 상업인접주거지 유형의 경우 과도하게 공급 되는 측면도 있었다. 특히 소도시로 갈수록 상업인접주거지 유형의 주차장 과다현상이 심해서 가로경관이 크게 변화되고 있었다. 공원은 기존지역 특히 상업인접지역에서 가장 숫자가 적게 나타났다. 그 외 커뮤니티시설이나 유치원 등 편의정도는 각 유형별로 크게 차이가 나지 않았다.

\section{V. 결론}

본 연구는 인구가 감소하는 지방중소도시 중 유사한 도시형성과정을 겪은 두 도시, 군산과 목 포를 대상으로 주거지형성과정을 면밀히 살펴보고자 하였다. 이를 통해 주거지의 형성과정에서 나타난 유형과 각 유형별 특성을 분석하여 인구 30만이하 중소도시의 주거지 특성을 제시하고 자 하였다. 본 연구는 최근 이슈가 되고 있는 도시재생뉴딜사업에서 주거지재생에 주거지형성 특성이 반영될 수 있도록 하는 학술적, 정책적 의의가 있을 것이다. 본 연구의 주요결과는 다음 과 같다.

첫째, 주거지를 형성하는 과정을 살펴보면 자연발생적인 요인도 있으나 한국전쟁이후 급격한 도시화과정에서 주거지는 정부주도의 정책을 실현하는 단위사업별로 특성이 구분되었다. 이를 바탕으로 본 연구에서 주거지유형을 기존지역(상업인접지역, 주거취약지역, 주거전이지역 구분 가능), 주거환경개선사업으로 구분되었고 신규조성된 지역은 토지구획정리사업(1980년이전과 이후 유형구분), 택지개발사업, 5층이하 공동주택사업, 재건축재개발사업으로 분류가 가능함을 제시하였다.

둘째, 연구대상으로 선정한 목포와 군산의 주거지공간구조는 기존지역의 주거지에서 신규개 발사업과 재개발, 재건축사업을 통해 주거지의 공간구조가 확장되는 형태를 보이고 있다. 위에 서 언급한 모든 주거지유형이 나타나고 있다는 점은 목포시와 군산시가 정부정책사업에 따라 주거지가 형성된 도시라는 점도 확인할 수 있었다.

셋째, 주거지유형별로 쇠퇴도, 활력도, 생활편의성을 조사분석한 결과 쇠퇴도의 주요양상은 
주택의 노후도와 함께 소필지비율이 높다는 점이다. 쇠퇴도가 높은 주거지유형은 기존도심의 주거지유형(상업인접, 일반주거, 토지구획정리지역)이므로 향후 이 지역의 주거지재생은 필지 에 대한 개선이 필요할 것이다. 활력도가 낮은 주거지유형은 기존지역(상업인접, 일반주거, 토 지구획정리지역)과 신규지역 중 저층공동주택지역인데, 근생비율보다는 빈집이나 빈점포수가 증가하고 있다는 점과 신축주택비율이 낮은 특성을 보였다. 생활편의성은 기존지역보다 신규지 역이 더 양호하여 정책사업으로 형성된 주거지역의 도시서비스의 수준이 더 높다는 것을 확인 하였다.

중도시의 주거지재생정책은 본 연구결과에서 보여지듯이 주거지유형을 고려하는 방향으로 전개되는 것이 바람직 할 것이다. 주거지 유형별로 쇠퇴도, 활력도, 생활편의성 측면에서 차이 를 보이고 있다는 점을 감안한다면 기존지역에서는 주택의 노후도를 개선할 수 있는 사업 뿐만 아니라 소필지체계를 개선할 수 있는 토지구획정리사업이 필요할 것으로 판단된다. 활력도측면 에서 근생비율이나 빈집이 많은 기존지역은 적극적으로 빈집정비가 필요한데 기존 빈집특별법 을 통해 소유자가 불분명하거나 매입이 어려운 경우에도 주거지정비차원에서 규제를 강화할 필 요가 있겠다. 생활편의성에서 기존지역의 수요를 충족시키는 방향으로 시행하되, 일부시설들은 기존지역의 국비지원사업으로 인해 과도공급되는 부분(주차장, 공원, 커뮤니티센터)에 대한 검 토가 필요할 것이다.

본 연구는 주거지정비·재생정책 및 사업을 진행하기 위한 정책적 기초 연구로 주거지형성의 공간구조를 분석하여 주거지를 유형화하고 각 유형별 특성을 분석함으로서 주거지정비의 방향 을 제시하였다는데 의의가 있다. 향후 도시재생활성화계획 수립시 본 연구에서 다룬 주거지유 형별 접근을 적용하여 주거지재생사업 시행시 지역맞춤형 시행이 될 것이다.

\section{참교문헌}

국토교통부(2016) 「2016년도 주거실태조사 연구보고서」

국토교통부(2011) 「정비사업 추진 실태조사 및 개선방안 연구」

국토교통부(2000)「21세기 대비 노후불량주택 정비제도 개선방안 연구」

국토교통부(2015)「재정비촉진사업 현황 분석 및 제도 개선방안 연구」

국토교통부(2013)「2단계 주거환경개선사업 성과평가 및 개선방안 연구」

국토교통부(2013)「지방중소도시 노후주거지 정비 방안 연구」

농림부(2011)「농촌중심지 정비방안 및 계획기법 현장실증 연구」 
국가건축정책위원회(2011)「서민저층주거지 통합적 근린재생 정책방안 연구」 대한주택공사(2000)「노후불량주거의 유형화와 정비체계 재구축 방안 연구」 지역발전위원회(2015)「2015년 지역생활권 지표 개발 및 행복도 조사」

맹다미·장남종·백세나(2017) 서울시 저층주거지 실태와 개선방향, 서울연구원 맹다미·장남종·백세나(2015) 서울시 주거환경관리사업의 추진실태와 개선방안, 서울연구원 박진경·김상민(2017) 인구구조 변화에 대응한 유형별 지역발전전략 연구, 한국지방행정연구원 이소영·김상민·최민정(2017) 인구감소지역 정주공간 현대화 및 생활서비스 지원체계 개선방안, 한국지방 행정연구원

나강열(2012) 전남 주거환경개선사업 실태분석 및 개선방안, 전남발전연구원

장남종(2015) 서울시 주거재생 지원모델의 실행 방안 연구, 서울연구원

조상규·권영상·김찬호(2011) 주거지 재생의 공익성 향상을 위한 공공의 역할, 건축도시공간연구소 박성남·김승남·윤주선(2016) 쇠퇴지역 공폐가 재생 및 활용 정책방안 연구, 건축도시공간연구소 이동현·김형균·황영우(2017) 부산광역시 주거환경관리사업의 유형화와 관리방안, 부산발전연구원 구형수 외(2016) 저성장 시대의 축소도시 실태와 정책방안 연구, 국토연구원 변필성·김동근·차은혜·이효란(2015) 지방중소도시 활성화를 위한 유형별 발전방향 연구, 국토연구원 박세훈 외(2017) 인구감소시대 지방중소도시 활력증진 방안, 국토연구원

최용환·김양식·정삼철·변혜선·배민기·김현기·조찬주(2015) 도민행복의 재발견 행복지수 연구, 충북발전 연구원

변미리·민보경·박민진(2017), 서울형 행복지표 구축과 제도화 방안, 서울연구원

신유진·이연숙(2016), 국내와 국외의 지속가능한 저층주거지 지원체계 비교 연구, 대한건축학회 학술발 표대회 논문집 페이지1290-1291.

양은정·박소현(2017), 군산시 원도심에 관한 계획방식의 변화와 특성:1960년대부터 2010년대까지의 군 산시 도시계획안 내용분석을 중심으로, 한국도시설계학회지 도시설계 18(5), 5-17

김항집(2011), 역사문화자원과 연계한 지방중소도시의 도시재생방안, 한국지역개발학회지 제23권 제4호, $123-148$

김병섭·박성현(2017), 지방 중소도시 원도심의 쇠퇴와 예측 그리고 대응방안: 목포시 사례를 중심으로, 한국지방행정학보, 제14권 제3호, 175-192

이민석·이정록(2015), 여수지역 도시활성화를 위한 입지특성의 분포지표에 관한 연구, 국토지리학회지 제49권 2호, 215-228

박종현·권영·이채성(2006), 일제강점기 신도시 공간구조 분석:군산시의 사례를 중심으로, 대한건축학회논 문집 계획계 22(7), 181-188

임석회(2018), 인구감소도시의 유형과 지리적 특성 분석, 국토지리학화지 제52권 1호, 65-84

황지욱·서충원(2006), 지방 노후 불량주택의 형성과정에 나타난 대표적 특성지구의 분석:군산시를 중심 으로, 한국지역개발학회 제18(1), 127-144

송석기(2008), 개항도시 목포와 군산의 구도심 공간 형성과정 비교, 대한건축학회논문집 계획계, 10(2), 
$149-158$

윤희철(2013), 일제강점기 목포 도시계획의 내용과 특징:시구개정과 시가지계획을 중심으로, 한국지역개 발학회지 25(2), 1-22

조준범(2005), 목포 구시가지도시조직의 형성과 변화에 관한 연구, 대한건축학회논문집 계획계, 21(10), 237-246

우승환·김행범·이석배(2011), 일제강점기 여수의 도시특성 변화에 관한 연구, 한국도시설계학회지 도시 설계 12(5), 103-121

원광희·채성주·송창식(2010), 인구감소시대 축소도시 활성화 전략:한국의 중소도시를 대상으로, 충북발전 연구원

박승규·이제연(2017), 인구감소지역의 지정기준과 시뮬레이션 연구, 한국지방행정연구원

박승규·박진경·조창덕(2015), 지역공동체 행복지표 개발에 관한 연구, 한국지방행정연구원

\section{온라인 사이트}

국토교통부(www.molit.go.kr)

국토교통부 주거복지로드맵(www.molit.go.kr/housingroadmap)

국토지리정보원 공간정보받기(http://map.ngii.go.kr/ms/map/NlipMap.do\#)

$\mathrm{LH}$ 한국토지주택공사(www.lh.or.kr)

LHI 토지주택연구원(Ihi.lh.or.kr)

$\mathrm{SH}$ 서울주택도시공사(http;//i-sh.co.kr) 